Syntax Idea: p-ISSN: 2684-6853 e-ISSN: 2684-883X

Vol. 3, No.10, Oktober 2021

\title{
TATANGAN DAN ISU STRATEGIS GERAKAN ANTIKORUPSI TERKINI
}

\section{Maman Budiman}

Fakultas Hukum Universitas Pasundan Bandung Jawa Barat, Indonesia

Email: maman.budiman@unpas.ac.id

\begin{abstract}
Abstrak
Tantangan yang dihadapi oleh bangsa Indonesia terhadap gerakan anti korupsi adalah adanya pelemahan kepada lembaga penegak hukum khususnya Komisi Pemberantasan Korupsi dalam melakukan pencegahan dan penindakan perkara tindak pidana korupsi seperti komposisi komisi penyelidik, penyidik dan penuntut umum, yang berasal dari kepolisian dan kejaksaan. Tujuan penelitian ini adalah untuk mengkaji faktor-faktor yang menyebabkan terjadinya perbuatan korupsi, mengkaji tantangan dan isu strategis yang dihadapi oleh bangsa Indonesia dalam gerakan anti korupsi serta mengkaji upaya yang harus dilakukan oleh pemerintah agar tantangan dan isu gerakan antikorupsi dapat teratasi. Metode penelitian yang digunakan adalah penelitian hukum normatif dengan mengkaji dan meneliti peraturan perundang-undangan. Hasil analisis menyimpulkan tindakan korupsi yang dilakukan disebabkan oleh beberapa faktor. Ada berasal dari faktor internal seperti sifat rakus atau tamak, faktor yang lainnya adalah gaya hidup yang konsumtif, faktor moral yang kurang kuat. Sedangkan faktor yang kedua adalah faktor eksternal seperti politik, faktor hukum, faktor ekonomi. Persoalan-persoalan tersebut menjadi tantangan dan isu yang strategis yang dihadapi oleh bangsa Indonesia dalam gerakan anti korupsi. Adanya lembaga Komisi Pemberantasan Korupsi yang dibentuk pada saat reformasi dirasa kurang optimal dalam hal pencegahan. Komisi Pemberantasan Korupsi (KPK) dibentuk karena lembaga hukum konvensional kurang optimal dalam hal pencegahan dan penindakan korupsi. Upaya yang harus dilakukan oleh pemerintah agar tantangan dan isu gerakan antikorupsi dapat teratasi adalah dengan mendeklarasikan bahwa korupsi merupakan musuh bangsa Indonesia.
\end{abstract}

Kata Kunci: tantangan; gerakan anti korupsi; KPK

\section{Abstract}

The challenge faced by the Indonesian nation against the anti-corruption movement is the weakening of law enforcement agencies, especially the Corruption Eradication Commission in preventing and cracking down on corruption crimes such as the composition of the commission of investigators, investigators and public prosecutors, which comes from the police and prosecutors. The purpose of this study is to examine the factors that cause corruption, examine the challenges and strategic issues faced by the Indonesian nation in the anti-corruption movement and review the efforts that must be made by the government so that the challenges and issues of the anti-corruption movement can be resolved. The research method used is normative legal research by reviewing and researching laws and regulations. The results of the analysis concluded that the acts of

$\begin{array}{ll}\text { How to cite: } & \text { Budiman. M., (2021) Tatangan dan Isu Strategis Gerakan Antikorupsi Terkini, Syntax Idea, 3(10), } \\ & \text { https://doi.org/10.36418/syntax-idea.v3i10.1504 } \\ \text { E-ISSN: } & \text { 2684-883X } \\ \text { Published by: } & \text { Ridwan Institute }\end{array}$


corruption committed were caused by several factors. There are derived from internal factors such as greedy or greedy nature, other factors are consumptive lifestyle, less powerful moral factors. While the second factor is external factors such as politics, legal factors, economic factors. These issues are a challenge and a strategic issue faced by the Indonesian nation in the anti-corruption movement. The existence of a Corruption Eradication Commission institution formed at the time of reform is considered less than optimal in terms of prevention. The Corruption Eradication Commission (KPK) was formed because conventional legal institutions are less than optimal in terms of prevention and enforcement of corruption. Efforts that must be made by the government so that the challenges and issues of the anticorruption movement can be resolved is to declare that corruption is an enemy of the Indonesian nation.

Keywords: challenges; anti-corruption movement; KPK

\section{Received: 2021-09-22; Accepted: 2021-10-05; Published: 2021-10-20}

\section{Pendahuluan}

Tindak pidana korupsi merupakan salah satu kejahatan kerah putih yang sering kali meresahkan masyarakat. Korupsi dalam segala bentuknya tentu saja membuat kesengsaraan bagi seluruh rakyat Indonesia. Hilangnya uang Negara dikarenakan korupsi tentu saja membuat hak-hak rakyat yang diatur oleh konstitusi dasar Indonesia yaitu Undang Undang Dasar Negara Republik Indonesia 1945 (UUD 1945) menjadi terabaikan. Hak-hak masyarakat untuk kesejahteraan seperti pendidikan, kesehatan, sandang, pangan, papan, sarana transportasi, akses terhadap teknologi menjadi sulit. Intinya adalah bahwa korupsi menghadirkan banyak kekecewaan bagi rakyat banyak. Korupsi pada dasarnya adalah menghabiskan anggaran negara yang awalnya ditujukan untuk kepentingan rakyat untuk kemudian diambil menjadi keuntungan pribadi atau sekelompok orang (Rambey, 2017).

Di Indonesia korupsi merupakan musuh bangsa yang harus diberantas. Korupsi adalah perbuatan jahat, busuk, tidak jujur, dan melawan hukum. Negara harus bertanggungjwab dalam hal pencegahan dan pemberantasan tindak pidana korupsi. Masalah korupsi sebenarnya bukanlah masalah baru di Indonesia, karena telah ada sejak era tahun 1950-an. Bahkan berbagai kalangan menilai bahwa korupsi telah menjadi bagian dari kehidupan (Arifin, 2015).

Berbagai cara telah dilakukan oleh negara untuk mencegah dan menindak pelakupelaku tindak pidana korupsi, termasuk membuat aturan atau regulasi. Perbuatan korupsi dari hari ke hari terus saja dapat terlihat dengan jelas, karena hampir setiap hari media baik cetak maupun elektronik memberitakan soal orang yang melakukan korupsi, baik itu pejabat, pegawai negeri sipil, kalangan swasta, pendidik, aparat penegak hukum (Sosiawan \& Indonesia, 2019).

Kondisi ini sesungguhnya telah disadari oleh bangsa Indonesia. Karena itu sejak reformasi bergulir, pemberantasan korupsi menjadi salah satu agenda prioritas. Bahkan hampir semua agenda reformasi, baik langsung ataupun tidak langsung ditujukan untuk 
meminimalisasi potensi korupsi, misalnya agenda perubahan UUD 1945 untuk membangun cheks and balancing system (system saling mengawasi dan mengendalikan) agar kekuasaan tidak terkonsentrasi pada satu cabang kekuasaan sehingga menimbulkan potensi korupsi (Fahrojih, 2016).

Dari segi regulasi pemerintah sudah beberapa kali melakukan perubahan Undangundang, dari mulai Undang-undang Nomor 3 tahun 1971, berubah menjadi Undangundang Nomor 31 tahun 1999, kemudian berubah lagi menjadi Undang-undang Nomor 20 tahun 2001, belum lagi ada Undang-undang Nomor 28 tahun 1999 tentang penyelenggaraan negara yang bersih dan bebas dari korupsi, kolusi dan nepotisme serta ada Undang-undang Nomor 30 tahun 2002 tentang Komisi Pemberantasan Korupsi. Dalam beberapa ketentuan Undang-undang tersebut diatas sangat jelas bahwa korupsi adalah kejahatan luar biasa (extra ordinary crime) yang sangat merugikan bangsa dan negara dan merusak sendi sendi kehidupan perekonomian. Perbuatan korupsi akan mengakibatkan dampak yang luar biasa sehingga penanganannyapun harus dilakukan secara luar biasa dan dengan cara khusus.

Cara penanganannya antara lain dengan memasukan sanksi yang berat dalam peraturan perundang-undangan seperti memberikan hukuman mati atau seumur hidup, mencabut hak-hak politik, merampas asset atau jika perlu memberikan sangsi sosial seperti mempekerjakan terpidana korupsi di lembaga-lembaga sosial.

Pencegahan dan pemberantasan tindak pidana korupsi tidak boleh berhenti dan harus terus dilakukan, Negara dan masyarakat tidak boleh kalah oleh orang-orang yang ingin mmemperkaya diri sendiri, memperkaya keluarganya dan memperkaya golongannya. Persoalan korupsi tidak akan berhenti untuk didiskusikan, dari mulai sebab sebab terjadinya perbutan korupsi, faktor-faktor yang menyebabkan perbuatan korupsi, serta upaya penanggulangannya.

Pencegahan yang dapat dilakukan antara lain dengan melakukan penguatan system, tata kelola yang baik, transfaran dan akuntabel. Selain itu dapat dilakukan sosialisasi atau penyuluhan yang terus menerus kepada penyelenggara negara, aparat penegak hukum serta masyarakat dan kalangan swasta. Negara tidak boleh menyerah, karena barangkali hasil penguatan system bisa terpakai 10 atau 20 tahun kemudian. Aspek penindakanpun harus terus dialkukan, hal itu semata-mata untuk memberikan efek jera kepada siapaun yang melakukan perbuatan korupsi agar memberikan penjeraan kepada pelaku dan menjadikan contoh bagi pelaku-pelaku lain yang akan melakukan perbuatan korupsi.

Penindakan yang dilakukan oleh aparat penegak hukum dari mulai proses penyelidikan, penyidikan, penuntutan dan pemeriksaan di pengadilan. Aparat penegak hukum dari mulai kepolisisan, kejaksaan, KPK dan Hakim harus profesional dan benar benar menjungjung tinggi independensi artinya harus benar benar menjaga kebebasan ketika memproses tindak pidana korupsi. Independensi terdapat dalam kehakiman di Indonesia diatur dalam Pasal 24 ayat (1) UUD NRI 1945, mengatur mengenai kekuasaan kehakiman yang merdeka untuk menyelenggarakan peradilan guna menegakkan hukum dan keadilan. Kemandirian peradilan adalah bebas dari segala 
bentuk intervensi. Hal tersebut agar kekuasaan kehakiman dapat menyelenggarakan peradilan guna menegakkan hukum dan keadilan berdasarkan Pancasila dan UUD RI 1945 (Sutatiek, 2013).

Penindakan yang dilakukan oleh aparat penegak hukum baik itu oleh kepolisian, kejaksaan dan KPK terkadang menemui hambatan seperti contohnya ada oknum-oknum yang menghalangi proses penyidikan perkara tipikor (obstruction of justice), melakukan kriminalisasi terhadp aparat penegak hukum, menghilangkan alat bukti, serta melemahkan lembaga penegak hukum supaya kewenangannya dibatasi dengan cara melakukan judicial riview Undang-undang Nomor 31 tahun 1999 jo Undang-undang nomor 20 tahun 2001 tentang pemberantasan tindak pidana korupsi serta undangundang nomor 30 tahun 2002 sebagaimana telah dirubah oleh Undang-undang Nomor 19 tahun 2019 tentang Komisi Pemberantasan Korupsi.

Dengan melihat kondisi diatas sudah seharusnya ada gerakan-gerakan yang dapat meminimalisir kejahatan korupsi. Masyarakat tidak boleh mengandalkan kepada aparat penegak hukum dan lembaga-lembaga swadaya masyarakat anti korupsi untuk melakukan perubahan agar bangsa Indonesia terlepas dari perbuatan-perbuatan koruptif. Gerakan-gerakan tersebut harus dimulai dari lingkunagn keluarga, Sekolah, Universtas, Instansi-instansi pemerintah, kalangan swasta, kalangan professional, seniman, dan olahragawan. penelitian ini dilakukan untuk mencari solusi terhadap tantangan dan isu strategis gerakan antikorupsi agar isu isu tentang pencegahan dan penindakan korupsi terus menerus di informasikan kepada semua lapisan masyarakat, hal ini sangat perlu dilakukan mengingat budaya korupsi di Indonesia sudah begitu mengakar dan sudah masuk ke sendi sendi kehidupan dari mulai bidang politik, hukum, ekonomi, sosial, kesehatan serta pendidikan. Selama ini penanganan korupsi cenderung tambal sulam sehingga satu kasus korupsi belum selesai ditangani sudah ada kasus korupsi yang lain lagi. Oleh karena itu, dalam penanganan masalah korupsi, diperlukan penanganan secara holistik atau menyeluruh, yaitu melalui kontrol preventif. Kontrol preventif tersebut dilakukan dengan cara membangun sistem hukum yang kuat yaitu sistem hukum yang berlandaskan kepada nilai-nilai moral dan budaya bangsa Indonesia, yakni Pancasila. Dengan membentuk suatu sistem hukum yang berdasarkan pada Pancasila diharapkan dapat menimalisir terjadinya korupsi (Teguh Prasetyo, 2014). Penanganan persoalan korupsi di Indonesia saat ini, selain dilakukan pencegahan dan penindakan oleh aparat penegak hukum diperlukan gerakan-gerakan yang masif mengenai isu-isu anti korupsi, sehingga dapat membantu memecahkan persoalah persoalan korupsi di Indonesia. Penelitian ini difokuskan kepada bagaimana upaya yang dilakukan oleh masyarakat, lembaga-lembaga masyarkat yang peduli terhadap persoalan korupsi di Indonesia agar budaya korup dimasyarakat, lembaga pemerintahan dapat diminimalisir sehingga kedepannya Indonesia dapat terbebas dari perilaku-perilaku korup. Dengan melihat latar belakang di atas, tulisan ini akan mengkaji mengenai tantangan dan isu strategis gerakan antikorupsi terkini. 


\section{Metode Penelitian}

Metode penelitian yang digunakan dalam tulisan ini adalah yuridis empiris yaitu penelitian atas kondisi gerakan anti korupsi di lapangan dikaitkan dengan isu isu politik yang terjadi di negara Indonesia. Kemudian menginventarisasi, mengkaji, dan meneliti data sekunder berupa peraturan perundang-undangan, asas-asas hukum, pengertianpengertian hukum.

Pengayaan data yang dilakukan dengan menggunakan pendekatan yuridisdogmatis yaitu dengan pendekatan konseptual, pendekatan peraturan perundangundangan, pendekatan perbandingan, dan pendekatan filosofis serta mengkaji gerakan antikorupsi pada saat ini. Beberapa pendekatan ini digunakan secara bersama-sama dalam rangka membahas setiap permasalahan.

\section{Hasil dan Pembahasan}

\section{Faktor-Faktor yang Menyebabkan Terjadinya Perbuatan Korupsi}

Perbuatan korupsi adalah perbuatan yang bertentangan dengan norma-norma yang terjadi dimasyarakat seperti norma hukum, norma agama dan norma adat. Tindakan korupsi harus dianggap sebagai kejahatan luar biasa karena dampak yang timbulnya adalah luar biasa. Orang yang melakukan perbuatan korupsi tidak memikirkan kepentingan masyarakat, mereka hanya mementingkan kepentingan pribadi, keluarga, dan golongannya serta untuk mencari kepuasan tersendiri yaitu mengumpulkan harta kekayaaan dari jalan yang tidak benar. Perilaku korupsi, selain melanggar berbagai aturan hukum juga melanggar nilai dan norma yang terkandung dalam UU No. 39 Tahun 1999 tentang HAM. Sebagaimana ketentuan dalam Pasal 1 yang menentukan bahwa "Hak Asasi Manusia adalah seperangkat hak yang melekat pada hakekat dan keberadaan manusia sebagai makhluk Tuhan YME dan merupakan anugrah-Nya yang wajib dihormati, dijunjung tinggi dan dilindungi oleh negara, hukum, pemerintahan, dan setiap orang demi kehormatan serta perlindungan harkat dan martabat manusia" (Dessy Rochman Prasetyo, 2016). Dampak dari tindak pidana korupsi selama ini, selain merugikan keuangan dan perekonomian negara, juga menghambat pertumbuhan dan kelangsungan pembangunan nasional yang menuntut efesiensi tinggi.

Tindak pidana korupsi bisa dilakukan oleh siapa saja, baik perorangan perusahaan berbadan hukum maupun tidak ber badan hukum, organisasi masyarakat, koperasi, yayasan dan anggota partai politik (Butarbutar, 2016). Pelaku korupsi tersebut tidak hanya dilakukan oleh para pejabat, birokrat, legislator, penegak hukum, kalangan swasta, dewasa ini menjamur sampai kepada masyarakat, contoh kecil pelayanan pembuatan kartu tanda penduduk, pelayanan pembuatan Ijin Mendirikan Bangunan, pelayanan asuransi kesehatan. Masyarakat Indonesia sedang sakit karena menganggap semua bisa didapat dan dilakukan dengan uang untuk mendapatkan sesuatu. Pola pemikiran ini yang harus dirubah, walaupun tidak mudah, karena korupsi yang ada di Indonesia bukan lagi sudah membudaya akan tetapi sudah masuk kedalam aliran darah masyarakat Indonesia. 
Perbuatan korupsi yang terjadi di Indonesia sudah berlangsung lama dan masif. Kalau melihat sejarah, perbuatan memberikan upeti pada masa jaman kerajaan dan pada zaman penjajahan baik pada saat di jajah Inggris, Perancis maupun oleh Belanda perbuatan perbuatan tersebut sudah ada. Perbuatan tersebut bertujuan untuk memudahkan suatu urusan sehingga masyarakat memberikan sesuatu kepada pemimpin.

Semangat untuk memberantas korupsi terkesan hanya menyalahkan system yang ada, tetapi kurang berorientasi kepada peningkatan dan pengawasan kinerja dan profesionalitas aparat penegak hukum, sehingga tidak jarang dalam proses pencegahan dan penindakan tindak pidana korupsi itu sendiri, terhalang oleh perilaku para penegak hukum yang menyalahgunakan kewenangan (abuse of power) (Chaerudin dkk, 2007).

Tindakan korupsi yang dilakukan disebabkan oleh beberapa faktor. Ada berasal dari faktor internal seperti sifat rakus atau tamak, artinya manusia tidak mudah puas dengan apa yang dimilikinya saat ini. Mereka cenderung merasa kurang dengan apa yang mereka miliki dan hal tersebut akan mendorong manusia tersebut untuk melakukan korupsi. Faktor yang lainnya adalah gaya hidup yang konsumif, yaitu dalam segi kehidupan sehari-hari berlebihan, atau dapat disebut juga dengan gaya hidup yang boros. Gaya hidup yang semacam ini akan mendorong untuk melakukan korupsi karena apabila dari penghasilan tidak mencukupi untuk memenuhi gaya hidupnya dan terakhir faktor moral yang kurang kuat, artinya moral yang dimiliki sangat kurang tidak tahan akan godaan duniawi, lebih mementingkan kepentingan pribadi, keluarga dan golongannya tidak memikirkan orang-orang disekelilingnya.

Sedangkan faktor yang kedua adalah faktor eksternal seperti politik, karena politik mempengaruhi terjadinya perbuatan korupsi. pada dasarnya politik berhubungan dengan kekuasaan yang artinya orang berpolitik akan menggunakan berbagai cara untuk mendapatkan kekuasaan, bahkan melakukan perbuatanperbuatan jahat seperti melakukan korupsi demi mendapatkan kekuasaan tersebut. Faktor politik terbagi menjadi dua yaitu faktor kekuasaan dan faktor stabilitas politik yang sedang berlaku. Faktor selanjutnya adalah faktor hukum, seperti kita ketahui sistem penegakan hukum yang hanya pro pada pihak-pihak tertentu saja yang memiliki kepentingan untuk dirinya sendiri, keluarga dan golongan tertentu akan menyebabkan hukum tumpul keatas dan tajam ke bawah. Faktor hukum dapat dibagi menjadi dua yaitu konsistensi penegakan hukum dan kepastian hukum.

Faktor yang lainnya adalah Faktor ekonomi yang menjadi salah satu faktor yang meyebabkan terjadinya korupsi. Hal tersebut dapat dilihat dari apabila gaji atau pendapatan seseorang tersebut tidak mencukupi untuk memenuhi kebutuhan hidup mereka sehari-hari akan timbul niat melakukan perbuatan korupsi. Faktor ekonomi terbagi menjadi dua yaitu faktor pendapatan atau gaji dan faktor sistem ekonomi, kemudian faktor organisasi dalam sebuah institusi baik pemerintahan, BUMN, BUMD, serta perusahaan swasta terkait dengan kultur atau budaya bekerja, faktor kepemipinan seorang pimpinan, faktor akuntabilitas dan faktor manajemen atau 
sistem. Faktor yang paling penting dalam dinamika korupsi adalah keadaan moral dan intelektual para pemimpin masyarakat. Keadaan moral dan intelektual dalam konfigurasi kondisi-kondisi yang lain (Hartanti, 2005). Faktor-faktor diatas menjadikan Indonesia sebagai negara yang tingkat korupsinya tinggi karena sudah sistemik merusak sendi-sendi kehidupan di dalam masyarakat. Perlu langkah strategis dan berani para pemimpin di negeri ini. Aparat penegak hukum harus berani memproses dan menjatuhkan hukuman yang berat kepada pelaku-pelaku korupsi agar menjadi efek jera bagi pelaku lain. Hukum pidana memberikan sanksi atau pidana dengan tujuan untuk melindungi masyarakat dari kejahatan. Ada tiga teori dan tujuan pemidanaan, yaitu: (1) Tujuan pembalasan (teori absolut), tujuan pemidanaan yaitu untuk membalas perbuatan pidana yang dilakukan oleh pelaku kejahatan; (2) Teori tujuan (teori relatif): a) untuk mencegah terjadinya kejahatan; b) untuk memberikan rasa takut, sehingga orang tidak melakukan kejahatan; c) memperbaiki orang yang melakukan kejahatan; d) memberikan perlindungan kepada masyarakat terhadap kejahatan (Muladi, 2005). Dengan melihat teori diatas tidak ada pilihan lain bagi para penegak hukum untuk tidak menjatuhkan hukuman maksimal bagi para pelaku tindak pidana korupsi agar minimal menjadi pengingat bagi pelakupelaku lain bahwa penindakan terhadap perilaku koruptif dapat dilakukan dengan maksimal dan terkadang kejam.

2. Tantangan dan isu strategis yang dihadapi oleh bangsa Indonesia dalam gerakan anti korupsi

Persoalan tindak pidana korupsi, tidak saja menuntut pembaharuan metode pembuktiannya, tetapi telah menuntut dibentuknya suatu lembaga di dalam upaya pemberantasannya. Pemerintah Indonesia telah berupaya melakukan usaha pencegahan dan pemberantasan tindak pidana korupsi baik yang bersifat preventif maupun refresif. Salah satu upaya tersebut membentuk lembaga pemberantasan tindak pidana korupsi, diluar kepolisian dan kejaksaan.

Dengan kerangka serupa, Ross McLeod menyatakan, gagalnya pemberantasan korupsi di Indonesia karena managemen sector public tidak dibenahi (Setiyono \& McLeod, 2010). Renumerasi pegawai tidak pernah diperbaiki tetapi pada saaat yang sama pegawai negeri diijinkan untuk melakukan korupsi berada dalam lingkungan yang tidak kompetitif). Mekanisme reward and punishment tidak berjalan.

Penanganan tindak pidana korupsi dalam sistem hukum di Indonesia memberikan kewenagan kepada tiga lembaga yaitu kepolisian, kejaksaan, dan KPK ketiga lemabaga ini punya kewenagan dalam melakukan penyelidikan dan penyidikan perkara korupsi. Jika terdapat kasus korupsi maka ketiga lembaga ini punya kewenagan untuk melakukan penyelidikan dan penyidikan khusus KPK salah satu kewenangannya adalah hanya akan menangani perkara yang melibatkan kerugian keuangan negara diatas 1 milyar, Pejabat Negara, dan aparat penegak hukum.

Keberhasilan lembaga penegak hukum dalam mencegah dan menindak perilaku koruptif sangat dirasakan oleh masyarakat. Lembaga Kepolisiaan, 
Kejaksaan, KPK sudah bekerja keras mencegah dan menindak pelaku-pelaku kejahatan korupsi akan tetapi perlu ditingkat lagi untuk meningkatkan kepercayaan publik tentang pencegahan dan pemberantasan korupsi yang tersebar luas di Indonesia. KPK dibentuk untuk melaksanakan tugas dan kewenangannya dalam pemberantasan korupsi di Indonesia yang bersifat independen dan bebas dari pengaruh kekuasaan manapun. Dalam hal ini, KPK bebas dari kekuatan yang dapat mempengaruhi tugas dan wewenang KPK atau anggota komisi secara individual dari pihak eksekutif, yudikatif, legislatif, pihak- pihak lain yang terkait dengan perkara tindak pidana korupsi, atau keadaan dan situasi ataupun dengan alasan apapun (Rizal \& Farid, 2017).

Penilaian masyarakat tentang kemajuan yang baik dalam memerangi korupsi, terkadang masih menghadapi masalah yang tidak bisa dianggap gampang. Masalah tersebut terdiri dari masalah internal dan masalah eksternal. Masalah internal seperti budaya ketidakenakan, budaya senioritas, budaya saling melindungi dan budaya melayani pimpinan. Masalah eksternal seperti sistem hukum, intervensi dari penguasa dan kepentingan politik dari penguasa.

Beberapa faktor yang dapat mencegah terjadinya tindak pidana korupsi, walaupun tidak akan memberantasnya adalah:

1. Keterikatan positif pada pemerintahan dan keterlibatan spiritual serta tugas kemajuan nasional dan public maupun birokrasi.

2. Administrasi yang efisien serta penyesuaian structural yang layak dari mesin dan aturan pemerintah sehingga menghindari penciptaan sumber-sumber korupsi.

3. Kondisi sejarah dan sosiologis yang menguntungkan

4. Berfungsinya suatu system yang antikorupsi

5. Kepemimpinan kelompok yang berpengaruh dengan standar moral dan intelektual yang tinggi (Hartanti, 2005).

Persoalan-persoalan tersebut menjadi tantangan dan isu yang strategis yang dihadapi oleh bangsa Indonesia dalam gerakan anti korupsi. Adanya lembaga Komisi Pemberantasan Korupsi yang dibentuk pada saat reformasi dirasa kurang optimal dalam hal pencegahan. Komisi Pemberantasan Korupsi (KPK) dibentuk karena lembaga hukum konvensional kurang optimal dalam hal pencegahan dan penindakan korupsi. Sudah 15 tahun KPK berdiri kejahatan luar biasa ini terus saja menjadi masalah besar bangsa ini, perlahan-lahan perilaku koruptif, penyelenggara negara, dari mulai menteri, gubernur, bupati dan walikota, anggota DPR, DPRD provinsi dan DPRD Kabupaten, Kalangan swasta, dan aparat penegak hukum seperti Hakim, Jaksa, Polisi dan Advokat tertangkap karena melakukan perbuatan korupsi.

Dengan melihat peroalan tersebut diatas, Indonesia perlu membangun sebuah sistem pencegahan dan penindakan yang terpadu. Akan tetapi hal itu tidak mudah karena dilapangan terkadang koruptor melakukan penyerangan balik, seperti mengkriminalisasi, mengancam atau percobaan pembunuhan. fenomena tersebut tidak heran karena pasti koruptor-koruptor yang dituduh telah merugikan keuangan Negara melakukan berbagai macam cara agar mereka tidak diproses hukum. Upaya 
meminimalisir korupsi antara lain dilakukan dengan menerapkan tata kelola pemerintahan yang baik. Tata kelola pemerintahan yang baik merujuk pada asas-asas umum pemerintahan yang baik (AUPB), yakni sebagai prinsip yang digunakan sebagai acuan penggunan Wewenang bagi Pejabat Pemerintahan dalam mengeluarkan Keputusan dan/atau Tindakan dalam penyelenggaraan pemerintahan apabila merujuk pada Pasal 1 angka 17 Undang-Undang Nomor30 Tahun 2014 tentang Administrasi Pemerintahan. Sedangkan berdasarkan Pasal 1 angka 7 Undang-Undang Nomor 28 Tahun 1999 tentang Penyelenggaraan Negara yang Bersih dan Bebas dari Korupsi, Kolusi, dan Nepotisme (UU Anti KKN) menyatakan Asas Umum Pemerintahan Negara yang Baik adalah asas yang menjunjung tinggi norma kesusilaan, kepatutan dan norma hukum, untuk mewujudkan Penyelenggara Negara yang bersih dan bebas dari korupsi, kolusi, dan nepotisme. kedua undang-undang tersebut menjelaskan asas-asas apa saja guna mewujudkan tata kelola pemerintahan yang baik, yakni asas kepastian hukum, kemanfaatan, ketidakberpihakan, kecermatan, tidak menyalahgunakan kewenangan, keterbukaan, kepentingan umum, dan pelayanan yang baik (Pasal 10 UU No. 30 Tahun 2014). Sedangkan dalam Pasal 3 UU Anti KKN, menyebutkan asas-asas umum penyelenggaraan negara meliputi asas kepastian hukum, asas tertib penyelenggaraan negara, asas kepentingan umum, asas keterbukaan, asas proporsionalitas, asas profesionalitas, dan asas akuntabilitas (Manurung, Sembiring, \& Sulistyani, 2019).

Tantangan yang dihadapi oleh aparat penegak hukum khususnya Komisi Pemberantasan korupsi dalam melakukan pencegahan dan penindakan perkara tindak pidana korupsi adalah masalah yang tidak bisa dianggap gampang adalah komposisi komisi penyelidik, penyidik dan penuntut umum, yang berasalal dari kepolisian dan kejaksaan walaupun dalam pasal 11 UU No 302002 mandat komisi meliputi memproses petugas penegak hukum. Melihat hal tersebut menjadai tantangan tersendiri bagi KPK untuk merekrut penyelidik, penyidik dan penuntut umum sendiri. Hal itu tidak mudah karena bertabrakan dengan ketentuan undang-undang yang lain yaitu undang-undang kepolisian dan undang-undang kejaksaaan.

Tantangan yang lain adalah melemahnya dukungan dari beberapa kalangan, terutama dari elit politik. Secara politis, pemberantasan korupsi belum menerima banyak dukungan. Sejauh ini hanya kelompok-kelompok masyarakat sipil dan media massa telah serius mempromosikan pemberantasan korupsi. Alasannya adalah bahwa agenda komisi telah menjadi ancaman serius bagi pejabat publik yang korup dan korup para elite partai politik. Parlemen tidak lagi kebal dari proses hukum untuk korupsi yang dimulai dan berkembang di sana. Tokoh politik terancam dan sekutu mereka telah digunakan atau telah merenungkan menggunakan metode berikut untuk mencoba dan melemahkan KPK.

Tantangan selanjutnya adalah budaya dimasyarakat yang menganggap bahwa perilaku koruptif sudah menjadi hal yang biasa dan itu diturunkan turun menurun dari orang tua kepada anaknya, hal ini yang menyebabkan tantangan tersendiri karena Negara yang diwakili oleh aparat penegak hukum selain melakukan 
penindakan harus juga diimbangi dengan proses pencegahan. Aparat penegak hukum harus memberikan contoh kapada masyarakat mengenai bahanya perilaku koruptif jangan sampai menjadi bagian dari system yang korup, karena untuk membersihkan Negara harus oleh orang-orang yang bersih, jujur, bermoral dan tentunya berintegritas.

Dengan melihat regulasi untuk pemberantasan korupsi sebenarnya sudah ada baik ditingkat internasioanal maupun nasional, hanya ketika diterapkan dilapangan banyak terkendala. Kendala-kendala dimaksud seperti budaya/culture, perilaku masyarakat, pola pikir, karakter serta system yang dibangun oleh Negara. Gerakan anti korupsi harus terus dilakukan dan di sosialisasikan, pemerintah harus menjadi garda terdepan dalam gerakan anti korupsi, dengan memberikan contoh perilaku yang tidak koruptif. masyarakat sipil (civil socity) tidak boleh lelah mengaspirasikan kegiatan-kegiatan anti korupsi.

\section{Upaya yang harus dilakukan oleh pemerintah agar tantangan dan isu gerakan antikorupsi dapat teratasi}

Definisi yang cukup dominan dalam pemberantasan korupsi adalah penyalahgunaan wewenang publik untuk kepentingan pribadi. Definisi ini menjadi arus utama dalam pemahaman tentang korupsi dan strategi pemberantasannya yang dipergunakan oleh bank dunia dan lembaga donor lainnya. Implikasi dari definisi dan strategi tersebut adalah fokus dalam pemberantasan korupsi di sektor publik. Praktis hampir semua program pemberantasan korupsi berpusat bagaimana mencegah penyalahgunaan wewenang public. Berbagai program kemudian difokuskan untuk mencegah penyalahgunaan wewenang di lembaga-lembaga pemerintahan (Setiyono $\&$ McLeod, 2010). Dalam ilmu politik, gagasan arus utama pemberantasan korupsi dikembangkan dari teori Principal-agent (Hamilton-Hart, 2001).

Senada dengan kerangka principal-agent, Robert Klitgaard membuat rumusan korupsi yang sangat terkenal: $\mathrm{C}=\mathrm{M}+\mathrm{D}-\mathrm{A}$ (Corruption $=$ Monopoli + DiscretionAccountability), (Klitgaard, 1988). Korupsi sama dengan monopoli ditambah dengan kewenangan tetapi minus akuntabilitas. Berdasarkan rumusan ini, maka program pemberantasan korupsi dirancang untuk mengurangi monopoli kekuasaan dan kewenangan serta meningkatkan akuntabilitas. Berdasarkan rumusan klitgaard itu, untuk mengurangi korupsi maka principal harus memastikan bahwa agen dibatasi kekuasaan dan kewenangannya serta menyiapkan mekanisme akuntabilitas. Dengan pegawasan yang ketat, maka korupsi atau penghianatan oleh agen bisa dikurangi (Setiyono \& McLeod, 2010).

Agenda pemberantasan korupsi kemudian diterjemahkan ke dalam sejumlah program seperti reformasi birokrasi berupa perbaikan sistem penggajian, recruitment, promosi dan mutasi. Program ini mendorong perubahan kearah merit system berdasarkan penilaian yang objektif., sedangkan praktik yang selama ini berkembang justru berdasar pada kedekatan pribadi dan penilaian subjektif (Setiyono \& McLeod, 2010). 
Berbicara mengenai cara menangani kasus korupsi, kolusi, dan nepotisme di Indonesia, tersedia ratusan bahkan ribuan solusi yang telah disalurkan melalui produk hukum, akademis ataupun wacana-wacana strategis (Setiawan, 2016). Pemerintah sudah bekerja keras membenahi budaya, sistem, perilaku, para penyelenggara Negara, pengusaha, aparat penegak hukum dan masyarakat. Hal itu bertujuan ingin melakukan pembenahan terhadap perilaku-perolaku korup. Upayaupaya sudah dilakukan oleh Pemerintah dengan membentuk system ekatalog dalam pengadaan barang dan jasa, memberikan punishment dan reward, melakukan perbaikan-perbaikan system birokrasi dan melakukan pengawasan melekat.

Permasalahan korupsi di negara Indonesia bukanlah sesuatu yang baru, sejak zaman kolonial sudah kita kenal budaya korupsi, dari mulai zaman Presiden Soekarno sampai Presiden Joko Widodo budaya ini tetaplah menjadi ciri khas dari Indonesia. Sebagai warga negara Indonesia menjadi kewajiban untuk mengurangi laju lahirnya generasi korupsi. Masyarakat Indonesia sudah seharusnya menjadi penghambat laju lahirnya koruptor di Indonesia. Upaya pemberantasan korupsi harus terus dilakukan di Indonesia. Masih banyak pekerjaan rumah yang mesti dilakukan agar upaya pemberantasan korupsi tetap fokus dan tidak menyimpang dari arahnya, sekaligus menjaga profesionalitas aparat penegak hukum agar pemberantasan korupsi tidak semena-mena.

Pendekatan yang dapat dilakukan terhadap masalah korupsi bermacam ragamnya, dan artinya tetap sesuai walaupun kita mendekati masalah itu, dari berbagai aspek. Pendekatan sosiologis misalnya, seperti halnya yang dilakukan oleh Syed Hussein Alatas dalam bukunya The Sociology of Corruption, akan lain artinya kalau kita melakukan pendekatan normatif; begitu pula dengan politik maupun ekonomi (Saragih, Prasetyo, \& Hafidz, 2018).

Korupsi adalah salah satu faktor yang paling berpengaruh dalam konteks kemajuan suatu bangsa, tantangan yang perlu dihindari agar pemberantasan korupsi bisa berjalan dengan baik adalah pembenahan sistem hukum kita, yang paling utama adalah jangan sampai terjadi diskriminasi dalam penegakan hukum di Indonesia, dimana sering kita lihat kasus rakyat miskin yang mencuri buah cokelat untuk memenuhi kehidupan keluarganya bisa dihukum oleh pengadilan, sedangkan koruptor yang telah mencuri hak-hak rakyat miskin hanya dihukum dengan hukuman ringan. Ketimpangan-ketimpangan ini yang harus segera dihapuskan, hukum di Indonesia tidak boleh "Tumpul ke atas dan tajam ke bawah", asas semua sama di mata hukum perlu kita junjung tinggi.

Selain dari masalah sistem hukum kita yang masih lemah, permasalahan moral bangsa menjadi suatu hal yang penting juga, setidaknya yang harus dilakukan oleh seluruh lapisan masyarakat adalah menanamkan nilai kejujuran, keadilan, mengedepankan kepentingan masyarakat dan tanggung jawab atas tugas dan kewajiban masing-masing serta adanya tanggung jawab atas keberhasilan dan kesejahteraan bangsa Indonesia yang bergantung pada tangan dan kontribusi besar masing-masing rakyat Indonesia. Jika dilakukan sesuai dengan tanggung jawab 
maksimal, kemungkinan terjadinya tindakan penyelewengan uang untuk kepentingan pribadi bisa kita kurangi.

Korupsi bisa merusak moral bangsa jika tidak diselesaikan sampai ke akarakarnya. Budaya rakyat Indonesia yang sering menganggap korupsi sebagai hal biasa bisa menjadi penghambat dalam pemberantasan korupsi, harus ada sikap yang berani untuk melaporkan kegiatan korupsi sekecil apapun ke penegak hukum agar terciptanya suasana aman dan harmonis di tengah masyarakat. Agar tercapainya Indonesia yang sejahtera korupsi harus diberantas. Ada beberapa peluang yang bisa dijadikan cara untuk memberantas korupsi, dimulai yang sifatnya preventif dengan cara mengajak masyarakat untuk bersama-sama mengawal pemerintah di daerahnya agar bisa mendorong sistem keterbukaan informasi publik yang bisa diakses kapan saja dan dimana saja. Dalam hal ini, peran masyarakat sebagai kontrol kebijakan pemerintah sangat diperlukan untuk mencegah kebocoran yang disebabkan oleh korupsi. Pendidikan karakter sejak dini juga bisa dikategorikan sebagai upaya preventif dalam peluang pemberantasan korupsi, di antaranya pendekatan secara agama, pendidikan moral di sekolah, dan yang paling penting adalah pendidikan di lingkungan keluarga. Pendidikan di lingkungan keluarga memiliki peranan yang sangat penting dalam hal tindakan preventif pemberantasan korupsi, karena tanpa kita sadari, keluarga menjadi salah satu pemicu seseorang untuk melakukan tindakan korupsi yang disebabkan pola hidup boros dan konsumtif yang dibina dari keluarga. Oleh karena itu, pendidikan anti korupsi dan penanaman pola hidup sederhana dalam keluarga menjadi hal yang paling utama dalam upaya pemberantasan korupsi.

Tindakan represif juga diperlukan dalam upaya pemberantasan korupsi, diantaranya dengan memperkuat sistem hukum di Indonesia dan juga bersama-sama memperkuat lembaga penegak hukum yang ada di Indonesia, seperti komisi pemberantasan korupsi (KPK), kejaksaan, dan Kepolisian Republik Indonesia. Jangan ada lagi upaya pelemahan KPK yang dilakukan oleh orang-orang yang tidak bertanggung jawab, seperti contoh kasus Abraham Samad dan Bambang Widjajanto, terlihat jelas bahwa ada unsur kriminalisasi yang dilakukan oleh institusi POLRI terhadap KPK. Dalam hal ini lembaga peradilan juga harus benar-benar objektif dalam menilai suatu kasus korupsi, praperadilan yang sudah memenangkan Budi Gunawan, Ilham Arief Sirajuddin, dan Hadi Poernomo menjadi bukti bahwa penegakan hukum di Indonesia masih sangat lemah dan ada upaya-upaya untuk melemahkan institusi pemberantasan korupsi.

Upaya yang harus dilakukan oleh pemerintah agar tantangan dan isu gerakan antikorupsi dapat teratasi adalah dengan mendeklarasikan bahwa korupsi merupakan musuh bangsa Indonesia, korupsi adalah perbuatan kejahatan luar biasa, korupsi merusak tatanan kehidupan berbangsa dan bernegara, Korupsi menghancurkan sistem perekonomian. Pemerintah tidak bisa berjalan sendiri dalam upaya pencegahan dan pemberantasan korupsi, perlu adanya kerja sama yang baik antara masyarakat dengan pemerintah agar terciptanya Indonesia yang terbebas dari korupsi di masa depan. Dalam rangka membangun strategi baru dalam pemberantasan tindak 
pidana korupsi, maka perlu dikaji secara komprehensif mengenai berbagai langkah dan capaian pemerintah dalam pemberantasan korupsi dari masa ke masa. Secara legal formil, arah dan kebijakan pemerintah dalam penanganan tindak pidana korupsi didasarkan pada politik hukum yang dibangun pada masa atau periode tertentu. (Alfarisi, 2019).

Program reformasi birokrasi pada unit kerja melalui upaya pembangunan Zona Integritas merupakan langkah kongkrit dalam melayani publik. Integritas harus diciptakan dalam lingkungan instansi pemerintah. Dalam rangka memberikan apresiasi kepada top manajemen yang memiliki komitmen terhadap pencegahan korupsi, Menteri PAN dan RB menerbitkan Permenpan dan RB Nomor 52 tahun 2014 tentang Pedoman Umum Pembangunan Zona Integritas Menuju Wilayah Bebas Dari Korupsi. Peraturan tersebut sebagai pedoman umum yang merupakan acuan bagi pejabat di lingkungan Kementerian/Lembaga dan Pemerintah Daerah (K/L/Pemda) dalam rangka Pembangunan Zona Integritas Menuju Wilayah Bebas dari Korupsi. K/L/Pemda yang telah mencanangkan kesiapan/ kesanggupan menjadi $\mathrm{K} / \mathrm{L} /$ Pemda yang berpredikat ZI mewujudkan komitmen pencegahan korupsi melalui pelaksanaan kegiatan-kegiatan pencegahan korupsi dalam bentuk yang lebih nyata secara terpadu dan disesuaikan dengan kebutuhan K/L/Pemda yang bersangkutan.

Di masyarakat sebenarnya telah ada lembaga-lembaga swadaya yang fokus terhadap pemantauan perilaku koruptif akan tetapi terkadang keberadaannya dianggap sebelah mata karena di tuduh sebagai alat luar negeri untuk memech belah bangsa Indonesia, pemerintah mesti berkolaborasi karena pemerintah akan mendapatkan masukan dari masyarakat khususnya dari LSM.

Pemerintah mesti memperkuat lembaga-lembaga penegak hukum, KPK tidak boleh dilemahkan, Kepolisian dan kejaksaan harus diperkuat dengan cara menunjuk para pemimpin di kedua lembaga tersebut yang diisi oleh orang-orang yang berintegrtas, berani, jujur, tidak pandang bulu, berorientasi kepada perubahan dan dan mempunyai rekam jejak yang baik yaitu tersandera kepada perbuatan masa lalu. Selain itu pemerintah mesti menganggarkan yang besar kjepada lembaga penegak hukum konvensuonal kepolisian dan kejaksaan, seperti KPK, karena dengan anggaran yang besar dapat menciptakan system pekerjaan yang baik dan menutup celah terjadinya penyalahgunaan kewenangan.

\section{Kesimpulan}

Kesimpulan dalam tulisan ini adalah bahwa ada 2 faktor yang menyebabkan tindakan korupsi yaitu faktor internal seperti sifat rakus atau tamak, gaya hidup yang konsumif, moralitas sedangkan faktor external meliputi faktor politik, hukum, ekonomi serta faktor organisasi dalam sebuah institusi baik pemerintahan, BUMN, BUMD, serta perusahaan swasta terkait dengan kultur atau budaya bekerja. Tantangan gerakan anti korupsi yang dihadapi adalah adanya pelemahan terhadap Komisi Pemberantasan Korupsi dalam melakukan pencegahan dan penindakan perkara tindak pidana korupsi, melemahnya dukungan dari beberapa kalangan, terutama dari elit politik serta budaya 


\section{Maman Budiman}

dimasyarakat yang menganggap bahwa perilaku koruptif sudah menjadi hal yang biasa dan itu diturunkan turun menurun dari orang tua kepada anaknya. Upaya yang harus dilakukan oleh pemerintah agar tantangan dan isu gerakan antikorupsi dapat teratasi adalah dengan mendeklarasikan bahwa korupsi merupakan musuh bangsa Indonesia, korupsi adalah perbuatan kejahatan luar biasa, korupsi merusak tatanan kehidupan berbangsa dan bernegara, korupsi menghancurkan sistem perekonomian serta perlu adanya kerja sama yang baik antara masyarakat dengan pemerintah agar terciptanya Indonesia yang terbebas dari korupsi di masa depan. 


\section{BIBLIOGRAFI}

Alfarisi, Fadli. (2019). Pembaharuan Strategi Pemberantasan Korupsi Di Indonesia. Fairness and Justice: Jurnal Ilmiah Ilmu Hukum, 17(2), 120-132.Google Scholar

Arifin, Siful. (2015). Model Implementasi Pendidikan Anti Korupsi di Perguruan Tinggi Islam. Jurnal Kariman, 3(1), 1-6. Google Scholar

Butarbutar, Russel. (2016). Pertanggungjawaban Pidana Partai Poli k dalam Tindak Pidana Korupsi dan Pencucian Uang. Padjadjaran Jurnal Ilmu Hukum, Unviersitas Padjadjaran, Bandung, 3. Google Scholar

Chaerudin dkk. (2007). Strategi Pencegahan dan Penegakan hukum. Jakarta: Refika aditama.

Fahrojih, Ikhwan. (2016). Hukum Acara Pidana Korupsi. Malang. Setara Press. Google Scholar

Hamilton-Hart, Natasha. (2001). Anti-corruption strategies in Indonesia. Bulletin of Indonesian Economic Studies, 37(1), 65-82. Google Scholar

Hartanti, Evi. (2005). Tindak pidana korupsi. Jakarta. Sinar Grafika. Google Scholar

Klitgaard, Robert. (1988). Controlling corruption. University of California press. Google Scholar

Manurung, Elsa Debora, Sembiring, Shafira Nadya Rahmayani, \& Sulistyani, Wanodyo. (2019). Pelayanan Publik Berbasis Elektronik dan Perilaku Anti Korupsi. Veritas et Justitia, 5(2), 399-420. Google Scholar

Muladi, Hak. (2005). Hak Asasi Manusia: Hakekat, Konsep dan Implikasinya dalam Perspektif Hukum dan Masyarakat. Google Scholar

Prasetyo, Dessy Rochman. (2016). Penyitaan dan Perampasan Aset Hasil Korupsi sebagai Upaya Pemiskinan Koruptor. DiH: Jurnal Ilmu Hukum, 12(24), 149-163. Google Scholar

Prasetyo, Teguh. (2014). Membangun Sistem Hukum Pancasila Yang Merdeka Dari Korupsi dan Menjunjung Ham. Refleksi Hukum: Jurnal Ilmu Hukum, 8(1), 19-26. Google Scholar

Rambey, Guntur. (2017). Pengembalian Kerugian Negara Dalam Tindak Pidana Korupsi Melalui Pembayaran Uang Pengganti dan Denda. De Lega Lata: Jurnal Ilmu Hukum, 1(1), 137-161. Google Scholar

Rizal, Moch Choirul, \& Farid, M. Lutfi Rizal. (2017). Pitutur Luhur Untuk Pemberantasan Korupsi Di Indonesia Dalam Perspektif Kebijakan Hukum Pidana. Refleksi Hukum: Jurnal Ilmu Hukum, 2(1), 33-50. Google Scholar 
Saragih, Yasmirah Mandasari, Prasetyo, Teguh, \& Hafidz, Jawade. (2018). Analisis Yuridis Kewenangan Komisi Pemberantasan Korupsi (KPK) sebagai Penuntut Pelaku Tindak Pidana Korupsi. UNIFIKASI: Jurnal Ilmu Hukum, 5(1), 33-44. Google Scholar

Setiawan, Azhari. (2016). ASEAN â€ ${ }^{\sim}$ Political-Securityâ€ ${ }^{\mathrm{TM}}$ Community: Mekanisme Kerjasama Multilateral dan Mutual Legal Assistance dalam Menangani Kasus Money Laundering di Asia Tenggara. Integritas: Jurnal Antikorupsi, 2(1), 69-89. Google Scholar

Setiyono, Budi, \& McLeod, Ross H. (2010). Civil society organisations' contribution to the anti-corruption movement in Indonesia. Bulletin of Indonesian Economic Studies, 46(3), 347-370. Google Scholar

Sosiawan, Ulang Mangun, \& Indonesia, HAMR. (2019). Peran Komisi Pemberantasan Korupsi (KPK) dalam pencegahan dan pemberantasan korupsi. Jurnal Penelitian Hukum De Jure, 19(4), 517-538. Google Scholar

Sutatiek, Sri. (2013). Akuntabilitas Moral Hakim dalam Memeriksa, Mengadili, dan Memutus Perkara Agar Putusannya Berkualitas. Arena Hukum, 6(1), 1-21. Google Scholar

Copyright holder:

Maman Budiman (2021)

First publication right:

Syntax Idea

This article is licensed under: 